Copyright (C) 2015 by Academic Publishing House Researcher

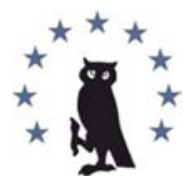

Published in the Russian Federation

European Researcher

Has been issued since 2010 .

ISSN 2219-8229

E-ISSN 2224-0136

Vol. 96, Is. 7, pp. 511-522, 2015

DOI: 10.13187/ er.2015.96.511

www.erjournal.ru

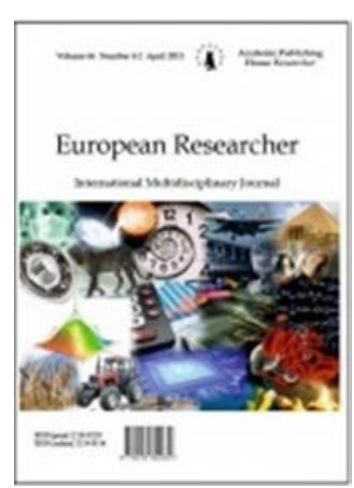

UDC 37

\title{
GIS as a Tool for Education Decision Support System: A Demonstration with Public Primary Schools in Zaria City Kaduna State Nigeria
}

\author{
1U. Wali \\ ${ }^{2}$ I.A. Musa
}

1-2 Abubakar Tafawa Balewa University Bauchi State Nigeria
Department of Surveying and Geoinformatics
E-mails: uwali24@yahoo.com, ishaqreal639@gmail.com

\section{Abstract}

This paper aimed at demonstrating the use of GIS in the display of data about primary schools in the walled part of Zaria city, Kaduna State. It is hoped that the database and its graphic display in maps will guide decision making at the primary education level in the study area. Coordinates of the schools were obtained with a handheld GPS receiver, while their attribute data were obtained from the local education authority and triangulated with questionnaires administered to the headmasters of the schools. ArcGIS 9.2 version software was used for buffer zone $(1 \mathrm{~km})$. The result indicates that there are 31 public primary schools in the study area. The oldest was established in 1921 and the latest in 2007. Graphic displays of some attributes of the schools were produced. The buffer zones produced suggest no pupil walks more than a kilometer to reach school. It is recommended that in the future, GIS tools should be applied when managing school data. Capacities to achieve this should be developed.

Keywords: primary school, GIS, digital map.

\section{Introduction}

Education is one of the most important factors in human capital development. Ehiozuwa (1997), defined education as a deliberate and systematic process of leading persons out of ignorance through instructions, discipline and collective development of physical, intellectual, aesthetics and spiritual faculties of the persons. Therefore, it is generally seen as any act or experience that has a formative effect on the mind, character or physical ability of an individual. It develops the intellectual and critical skills of individuals, societies and nations thereby making it one of the main factors in the spread of civilization. Little wonder governments prioritize the provision of education to its citizens. In fact in tune with Article 13 of the United Nations 1966 international covenant on economic, social and cultural rights, the governments of most recognize basic formal education as a human right. Individuals also strive to acquire it and support those under their care to be educated J aiyeoba (2007). 
Education can either be acquired informally or formally. Informal education is that acquired outside a school environment. On the other hand, formal education occurs in a structured environment whose explicit purpose is teaching students by trained instructors. This happens in school set ups with requisite infrastructures (classrooms, furniture, books, toilets, libraries, laboratories, etc). Formal schools have a chronology of kindergarten (pre- primary), primary (elementary), secondary, and tertiary levels. Such schools can be owned by individuals (private) or governments (public). Both are however, expected to operate within government prescribed guidelines and standards. In public schools, the onus for providing their operational requirements is on the governments through relevant agencies. Primary schools, which are the focus of this study, are schools for children between the ages of 5 and 11. They are not only the foundations of the educational system that determines its success or failure, but are also the largest sector. Thus public primary schools are primary schools owned by the government.

In Nigeria, the government recognized the right of the citizens to primary education in 1976. Section 3 of the National Policy on Education is specific on primary education (FRN, 2004). Among other things, the section specified the objectives of primary education and a teacher-pupil ratio of 1: 35 .

Some studies have highlighted the problems of primary education in Nigeria. The problems identified include problems of shortage of classrooms leading to overcrowding, shortage of teachers, libraries and other learning infrastructures ( Domike \& Odey, 2014). These problems are mostly narrated in analogue texts which deteriorate with time. Compared with maps, these texts are less discernible and more difficult to update.

The advent of Geographic Information Systems (GIS) has made it possible to display a variety of phenomena in graphic forms (maps and charts) that are easily appreciated. GIS tools have been used to create comprehensive data bases that provide the framework and organization of spatial as well as non- spatial data thereby making it helpful in planning and decision making. In the education sector, GIS has been applied as a tool for Educational Decision Support System (EDSS). This realm of GIS applicability EDSS has been demonstrated in various studies. These studies include Banskota (n.d), Hite (2008), Aliyu, Sule \& Youngu (2012), Abbas (2012) and, Olubadewo, Abdulkarim \& Ahmed (2013). This paper is a further demonstration of how GIS can be used to display education information graphically. Zaria, a town in Kaduna State, Nigeria is the locale of the study that is concerned about public primary schools in a part of the town. It appears such a study has not been done before now. It is hoped that the study will help in the management of the schools involved. A $1 \mathrm{~km}$ buffer zone was created to investigate whether there are pupils that have to walk more than a kilometre before getting to school. Apart from attributes of location, year of establishment, enrolment, number of classrooms and teachers, other aspects of school attributes were not included.

\section{Aim and Objectives}

The aim of this study is to map and produce a digital map showing the spatial distribution of all public primary schools in the walled part of Zaria city. The specific objectives of the study were to:

(i) Identify and locate all public primary schools in Zaria City

(ii) Obtain the attribute data of the public primary schools

(iii) Map the public primary schools in the study area and create a $1 \mathrm{~km}$ buffer zone for the schools 


\section{The Study Area}

The study area is located between latitude $11^{\mathrm{o}} 15^{\prime} \mathrm{N}$ and $11^{\circ} 04^{\prime} \mathrm{N}$ of the equator and longitude 070 30' E and 070 42' E of the Greenwich meridian. It is about 78km South of Kaduna, the Kaduna State Capital. It has been the administrative capital of Zazzau emirate established by the Sokoto caliphate and a Local Government head quarter since 1976. The settled population in Zaria is pre-dominantly Hausa and Fulani. According to the last census conducted in Nigeria in 2006, the population of Zaria was 408,198 people (NPC, 2006). The town is reputed as a center of both Islamic and western education. In addition to several primary and secondary schools, the Ahmadu Bello University, and Nuhu Bamalli Polytechnic are sited in the town.

\section{Methodology}

A trip was made to schools in the study area and coordinates of each school were obtained using the Garmin 75S Handheld GPS receiver and the attribute data was obtained from Zaria Local Education Authority (LEA) which includes the names of existing schools, street, year of establishment, school code, number of teachers per each school, number of classrooms each school. This information was further confirmed at the schools through questionnaires. These data are useful for various types of analysis which will greatly assist in the efficient and effective planning and management of school resources. The digital base map of the study area was obtained by digitizing Google Pro 2008 satellite image. In digitizing the feature classes, the Google satellite image was used to map the features classes. First, it was downloaded from the internet so that the satellite image could be seen for accurate mapping. The digitizing exercise then started by adding the layers that were created in Arc Catalog. The start editing was activated in the editor tool and features classes were digitized by selecting the "create New Features" in the Task drop-down menu. The pencil icon was clicked and the pointer becomes a small crosshair symbol. A homogeneous area was picked and the vertices of the poly-gon were created by "tracing" the boundary and clicking at each vertex.

The coordinates of the schools that were obtained using the hand held GPS receiver were imputed into the computer in notepad with .txt format. The ArcGIS software was used in plotting these coordinates using the following procedure: First, the software was launched. The base map was added by clicking add data and georeferenced using (UTM) coordinate system. The points defined by coordinates were plotted onto the base map, by selecting tools and add XY data.

\section{Results}

As revealed by Table 1, there are 31 public primary schools in the study area. Their names and coordinates are as displayed by the table. The schools are named after prominent citizens of the study area. Figure 1 is a representation of the data in Table 1 in form of a map. 
Table 1: Public primary schools and their locations

\begin{tabular}{|c|c|c|c|c|}
\hline Shape & S/NO & NAMES OF SCHOOLS & NORTHING & EASTHING \\
\hline Point & 1 & ABDULKARIM & 1223957.71 & 358395.69 \\
\hline Point & 2 & ABDULSALAM & 1221536.53 & 358395.69 \\
\hline Point & 3 & AHMAD FATIKA & 1224050.27 & 359454.17 \\
\hline Point & 4 & ALIYU LIMAN KONA & 1221805.43 & 357701.8 \\
\hline Point & 5 & ALKALI GAMBO & 1224410.97 & 357557.22 \\
\hline Point & 6 & ALU DANSIDI & 1224625.53 & 358381.64 \\
\hline Point & 7 & AMBASADA LAWAL SAMBO & 1221272.8 & 358742.35 \\
\hline Point & 8 & DAHIRU KANTI & 1222212.69 & 360093.09 \\
\hline Point & 9 & DALLATU SAMA'ILA & 1224225.36 & 357652.4 \\
\hline Point & 10 & DANMADAMI(Dr.AMINU LADAN) & 1221377.03 & 356772.02 \\
\hline Point & 11 & DR.NUHU BAYERO & 1222050.74 & 359012.52 \\
\hline Point & 12 & DR.SHEHU IDRIS & 1223146.67 & 358532.06 \\
\hline Point & 13 & GALADIMA ADAMU & 1221284.41 & 358321.47 \\
\hline Point & 14 & JUSTICE BASHIR SAMBO & 1224197.13 & 360179.24 \\
\hline Point & 15 & LAWAL ALIYU MAGAJIN MALLAM & 1223961.69 & 358694.44 \\
\hline Point & 16 & LIMAN KWAIRE & 1224062.73 & 360506.68 \\
\hline Point & 17 & DR.MOH'D JUMARE & 1224758.62 & 356841.69 \\
\hline Point & 18 & NUHU BAMMALLI & 1224539.48 & 358450.08 \\
\hline Point & 19 & NUHU BATUREN MAKARANTA & 1222567 & 359054.83 \\
\hline Point & 20 & SARKI MUSA & 1224577.8 & 359363.48 \\
\hline Point & 21 & SARKI JAFA'ARU & 1222025.65 & 359050.54 \\
\hline Point & 22 & SARKI SAMBO & 1223483.33 & 358477.66 \\
\hline Point & 23 & TURAKI ALLI & 1223078.79 & 358761.69 \\
\hline Point & 24 & WAZIRI LAWAL & 1222436.18 & 359798.59 \\
\hline Point & 25 & YAHAYA HAMZA & 1221473.39 & 357155.95 \\
\hline Point & 26 & YA MUSA & 1221557.42 & 359976.01 \\
\hline Point & 27 & KAGE ZAGI & 1224288.46 & 359793.78 \\
\hline Point & 28 & KOASFA KIBO & 1224558.5 & 358984.96 \\
\hline Point & 29 & 1220882.82 & 358486.38 \\
\hline Point & 30 & 1221785.76 & 359366.16 \\
\hline Point & 31 & 1222250.65 & 358555.27 \\
\hline & & & \\
\hline
\end{tabular}




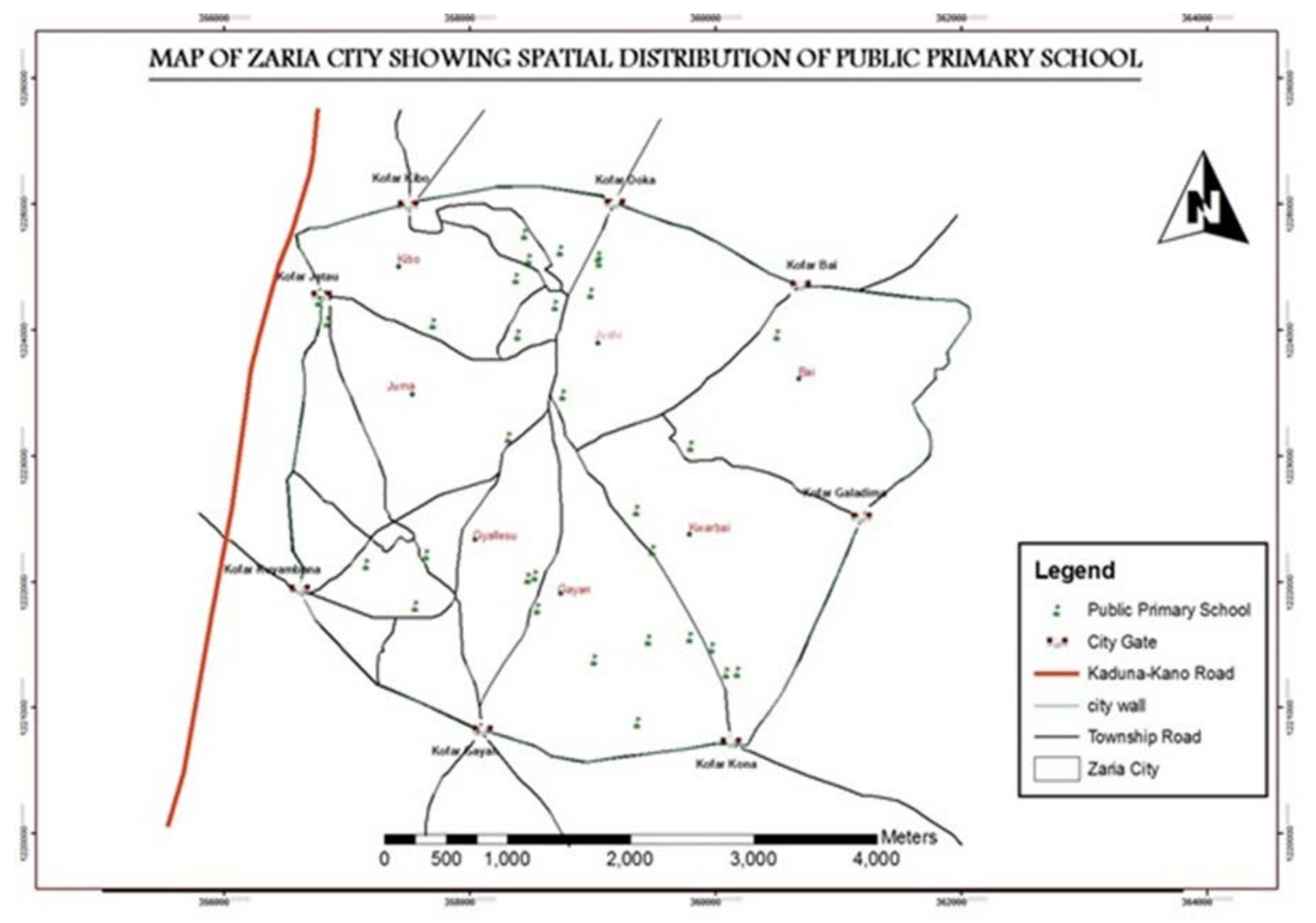

Figure 1: Spatial Distribution of Public Primary Schools in Zaria City

The chronology of the years and the number of schools established in each of the years is: 1921 (1), 1942 (2), 1945 (1), 1960 (4), 1962 (1), 1966 (1), 1969 (1), 1970 (1), 1975 (2), 1976 (11), 1977 (1), 1997 (1), 1998 (1), 2000 (1), 2005 (1), and 2007 (1). The highest number of new schools in a year was in 1976 when 11 schools were established. The enrolment of pupils in the schools range from 367 in Zage zagi primary school to 2641 in Dr Shehu Idris primary school. As for the number of classrooms, Ya Musa primary school has the least (2) while Dr Shehu Idris primary school which has the highest enrolment, also has the highest number of classrooms (23). Waziri Lawal primary school has the highest teachers (65) while Professor Idris Abdulkadir primary school has the least (7). Table 2 shows the names of the schools, the names of the wards in which they are located, the years they were established, the enrolment of pupils, the number of classes and the number of

Table 3 presents the enrolment of the schools, the number of teachers available and those required, the number of classes available and those required. In deducing the number of teachers and classes required, the teacher pupil ratio of 1: 35, as recommended by the National Policy of Education was used. The additional teachers and classes required range from 10 in Zagezagi primary school to 76 in Dr Shehu Idris. To demonstrate how GIS can be used to depict information about schools, Figure 2 display the schools with at least 15 classrooms, Figure 3 show schools that were established in 1976, while Figure 4 show schools with at least 17 teachers. Assuming that primary school pupils (on account of their young ages, 6 to 11 years) should not walk longer than $1 \mathrm{~km}$ to reach their schools, a buffer radius of $1 \mathrm{~km}$ was chosen. The buffer created is shown in Figure 5. 
Table 2: Attribute Information of Public Primary Schools in the Study Area

\begin{tabular}{|c|c|c|c|c|c|c|c|}
\hline$S / \mathbb{N}$ & NAME_OF_SCHOOLS & LOCATION & YEAR_OF_EST & SCH_CODE & NO_OF_PUPILS & NO_OF_CLSS & NO_OF_TEAC \\
\hline 1 & Abdulkarim Primary School & Anguwan Alkali & 1975 & 1923122020 & 994 & 9 & 9 \\
\hline 2 & Abdulsalam Primary School & Anguwan Bisha & 1975 & 1923027120 & 827 & 10 & 29 \\
\hline 3 & Ahmad Fatika Primary School & Anguwan Fatika & 1969 & 1923031120 & 1408 & 9 & 26 \\
\hline 4 & Aliyu Liman Kona Primary School & Limancin Kona & 1998 & 1923034120 & 1188 & 10 & 20 \\
\hline 5 & Alkali Gambo Primary School & Anguwan Alkali & 1976 & 1923035120 & 803 & 7 & 24 \\
\hline 6 & Alu Dansiail Primary School & Jamawa & 1942 & 1923036120 & 1581 & 20 & 43 \\
\hline 7 & Ambassador Lawal Sambo Primary Sc & Kofar Kona & 1976 & 1923037120 & 670 & 8 & 15 \\
\hline 8 & Dahiru Kanti Primary School & Rimin Danza & 1976 & 1923045120 & 1007 & 11 & 25 \\
\hline 9 & Dallatu Sama'ila Primary School & Kofar Jatau & 1976 & 1923047120 & 1501 & 10 & 20 \\
\hline 10 & Danmadami Primary School & Fan Wanki & 1977 & 1923049120 & 1618 & 14 & 40 \\
\hline 11 & DR.Nuhu Bayero Primary School & Kaura & 1960 & 1923052120 & 1871 & 18 & 36 \\
\hline 12 & DR.Shehu Idris Primary School & Babban Dodo & 1960 & 1923053120 & 2641 & 23 & 48 \\
\hline 13 & Galadima Adamu Primary School & Kofar Galadima & 1976 & 1923056120 & 388 & 8 & 17 \\
\hline 14 & Justice Bashir Sambo Primary School & Lemu & 1960 & 1923061120 & 1243 & 11 & 36 \\
\hline 15 & Lawal Aliyu Magajin Mallam Primary S & Ban Zazzau & 1976 & 1923055120 & 865 & 13 & 40 \\
\hline 16 & Liman Kwaire Primary School & Alfadarai & 1960 & 1923066120 & 1348 & 6 & 21 \\
\hline 17 & DR.Moh;d Jumare Primary School & Jushi & 1976 & 1923070120 & 1599 & 8 & 25 \\
\hline 18 & Nuhu Bammali Primary School & Kwarbai & 1976 & 1923071120 & 691 & 11 & 21 \\
\hline 19 & Nuhu Baturen Makaranta Primary Scho & Anguwan kahu & 1945 & 1923072120 & 1640 & 15 & 38 \\
\hline 20 & Sarki Musa Primary School & Kwarbai & 1966 & 1923081120 & 857 & 15 & 44 \\
\hline 21 & SarkiJa'afaru Primary School & Mazangudu & 1942 & 1923082120 & 2616 & 12 & 41 \\
\hline 22 & Sarki Sambo Primary School & Fada & 1962 & 1923083120 & 1566 & 18 & 36 \\
\hline 23 & Turaki Ali Primary School & Magajiya & 1970 & 1923088120 & 1131 & 13 & 31 \\
\hline 24 & Waziri Lawal Primary School & Anguwan lya & 1921 & 1923090120 & 2561 & 18 & 65 \\
\hline 25 & Yahaya Hamza Primary School & Anguwan Lima & 1976 & 1923091120 & 715 & 12 & 33 \\
\hline 26 & Ya Musa Primary School & Rimin Doko & 1976 & 1923092120 & 806 & 2 & 17 \\
\hline 27 & Zage Zagi Primary School & Zage-Zagi & 1976 & 1923049120 & 357 & 6 & 17 \\
\hline 28 & Kofar Kibo Primary School & Kofar Kibo & 2000 & 1923123120 & 589 & 8 & 17 \\
\hline 29 & Kusfa Primary School & Kusfa & 2005 & 1923128120 & 743 & 9 & 11 \\
\hline 30 & Prof.Idris Abdulkadir Primary School & Karufin Taba & 2007 & 1923129120 & 587 & 4 & 7 \\
\hline 31 & Zubairu Isah Raka Primary School & Salmanduna & 1997 & 1923096120 & 948 & 6 & 19 \\
\hline
\end{tabular}


Table 3: Teachers and Classes Available and those Required

\begin{tabular}{|c|c|c|c|c|c|c|}
\hline $\mathrm{S} / \mathrm{NO}$ & NAMES Of SCHOOLS & PUPILS & TEACHERS AVAILABLE & TEACHERS REQUIRED & CLASSES AVAILABLE & CLASSES REQUIRED \\
\hline 1 & ABDLLKARIM & 994 & 9 & 29 & 9 & 29 \\
\hline 2 & ABDLTSALAM & 827 & 29 & 24 & 10 & 24 \\
\hline 3 & AHMLAD FATIKA & 1408 & 26 & 41 & 9 & 41 \\
\hline 4 & ALIYU UMANKONA & 1188 & 20 & 34 & 10 & 34 \\
\hline 5 & ALKALI GAMBO & 803 & 24 & 23 & 7 & 23 \\
\hline 6 & ALUDANSIDI & 1581 & 43 & 45 & 20 & 45 \\
\hline 7 & AMBASADALAWALSAMBO & 670 & 15 & 19 & 8 & 19 \\
\hline 8 & DAHIRL KANTI & 1007 & 25 & 29 & 11 & 29 \\
\hline 9 & DALLATL SAMATLA & 1501 & 20 & 43 & 10 & 43 \\
\hline 10 & DANMADAMI(DRAMINUL LADAN) & 1618 & 40 & 46 & 14 & 46 \\
\hline 11 & DRNLHL BAYERO & 1871 & 36 & 54 & 18 & 54 \\
\hline 12 & DRSHEHL IDRIS & 2641 & 48 & 76 & 23 & 76 \\
\hline 13 & GALADIMAADAMU & 388 & 17 & 11 & 8 & 11 \\
\hline 14 & JUSTICE BASHIR SAMEO & 1243 & 36 & 36 & 11 & 36 \\
\hline 15 & LAWALALNU MAGATIN MALLAM & 865 & 40 & 25 & 13 & 25 \\
\hline 16 & LIMLAN KWAIRE & 1348 & 21 & 39 & 6 & 39 \\
\hline 17 & DRMOHD ILMLARE & 1599 & 25 & 46 & 8 & 46 \\
\hline 18 & NLHL BAMLALLI & 691 & 21 & 20 & 11 & 20 \\
\hline 19 & NLHL BATLRENMAKARANTA & 1640 & 38 & 47 & 15 & 47 \\
\hline 20 & SARKI MUSA & 857 & 44 & 25 & 15 & 25 \\
\hline 21 & SARKI HAFARL & 2616 & 41 & 75 & 12 & 75 \\
\hline 22 & SARKI SAMBO & 1566 & 36 & 45 & 18 & 45 \\
\hline 23 & TLRAKI ALUI & 1131 & 31 & 32 & 13 & 32 \\
\hline 24 & WAZIRI LAWAL & 2561 & 65 & 73 & 18 & 73 \\
\hline 25 & YAHAYA HAMZA & 715 & 33 & 21 & 12 & 21 \\
\hline 26 & YAMUSA & 806 & 17 & 23 & 2 & 23 \\
\hline 27 & $2 A G E 2 A G I$ & 357 & 17 & 10 & 6 & 10 \\
\hline 28 & KOFAR KIBO & 589 & 17 & 17 & 8 & 17 \\
\hline 29 & KLSfA & 743 & 11 & 21 & 9 & 21 \\
\hline 30 & FROf IDRIS ABDLLKADIR & 587 & 7 & 17 & 4 & 17 \\
\hline 31 & 2LBAIRL ISAH RAKA & 948 & 19 & 27 & 6 & 27 \\
\hline
\end{tabular}




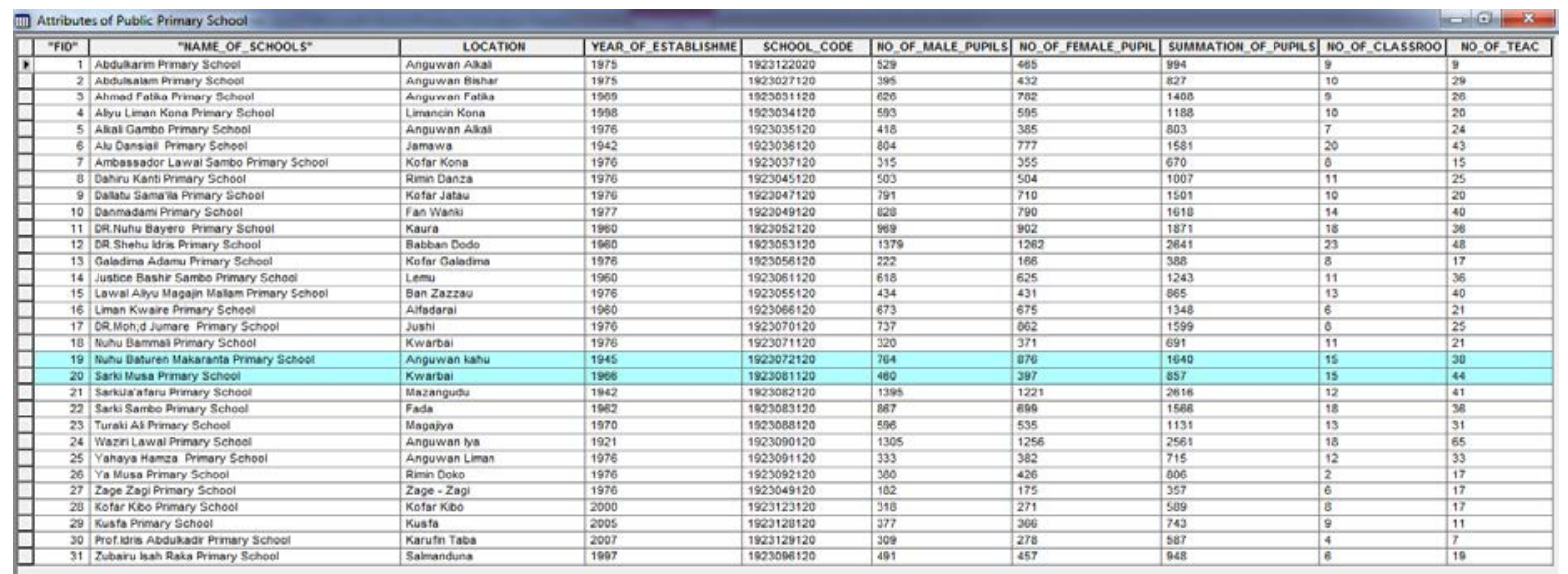

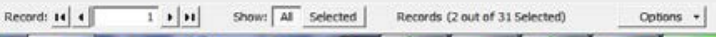

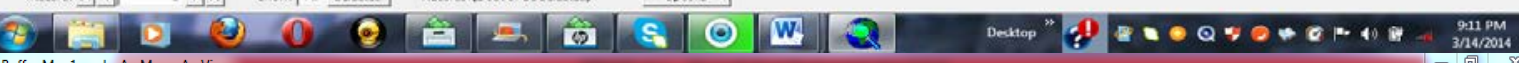

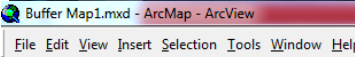

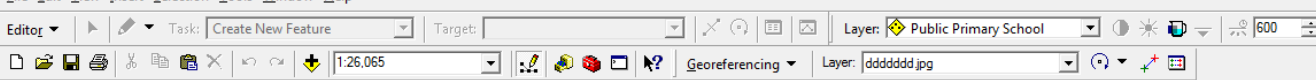

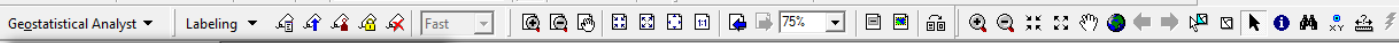

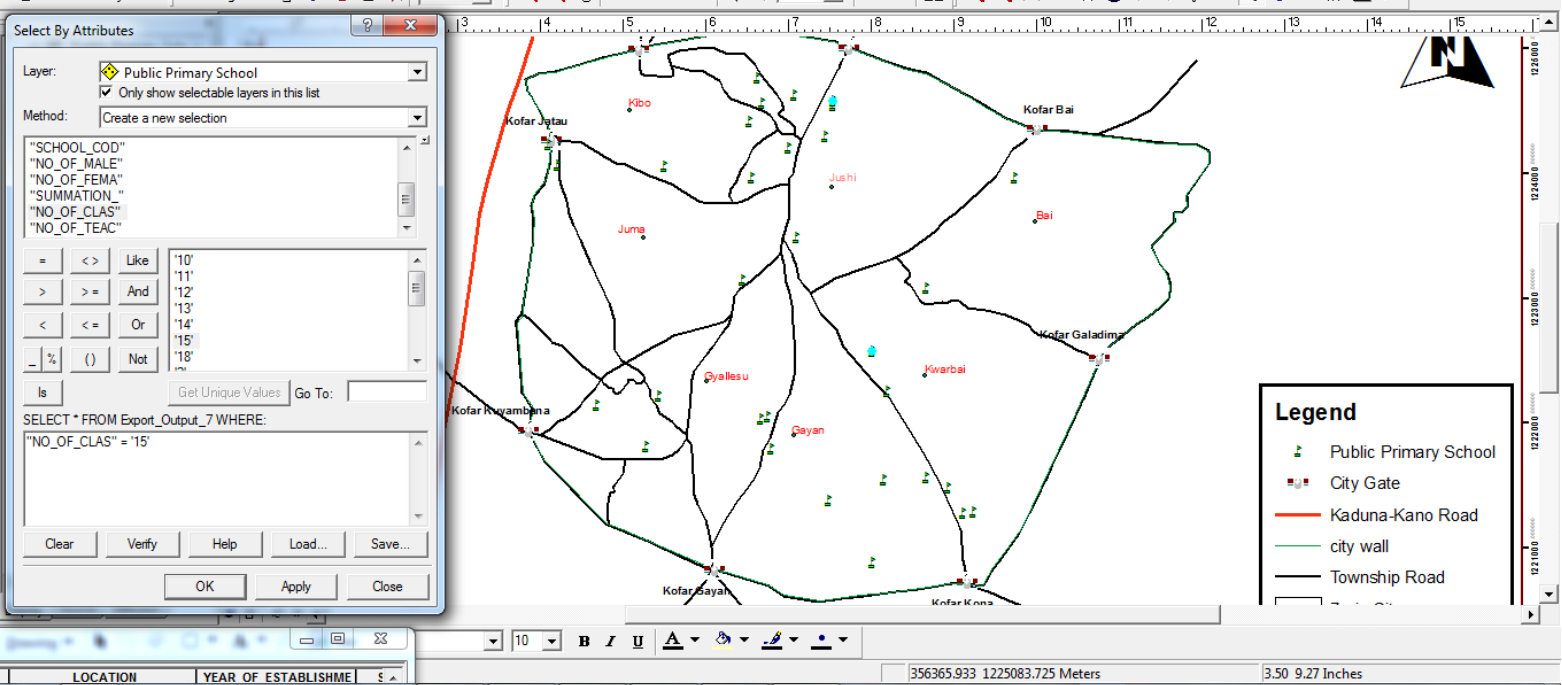

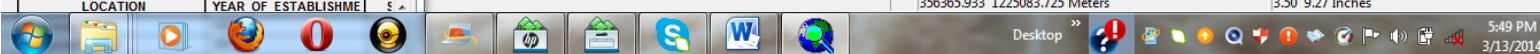

FIG 2: Query on schools that have $\geq 15$ classes 


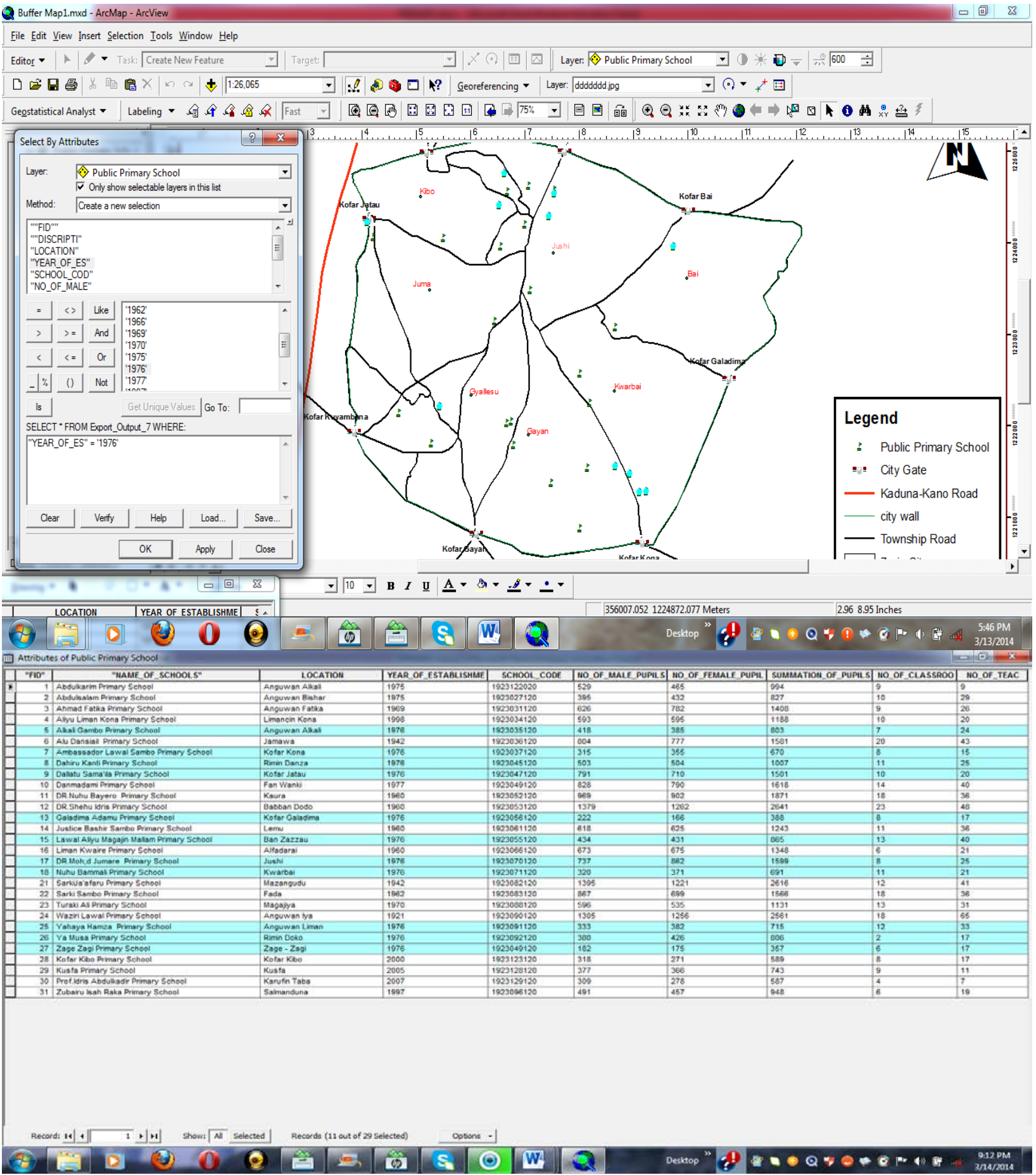

Figure 3: Schools established in 1976 


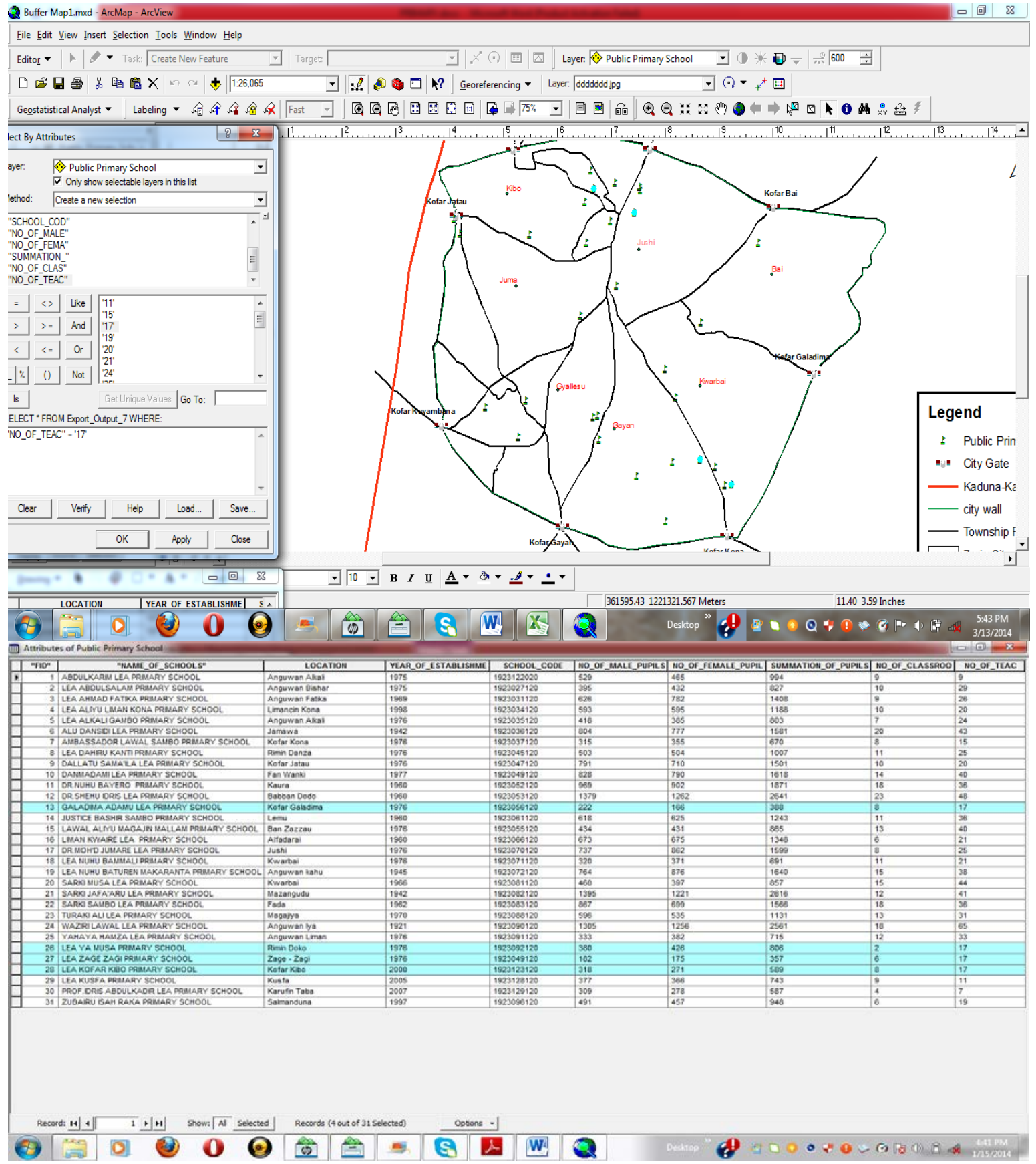

Figure 4: Schools with 17 teachers in the study area 


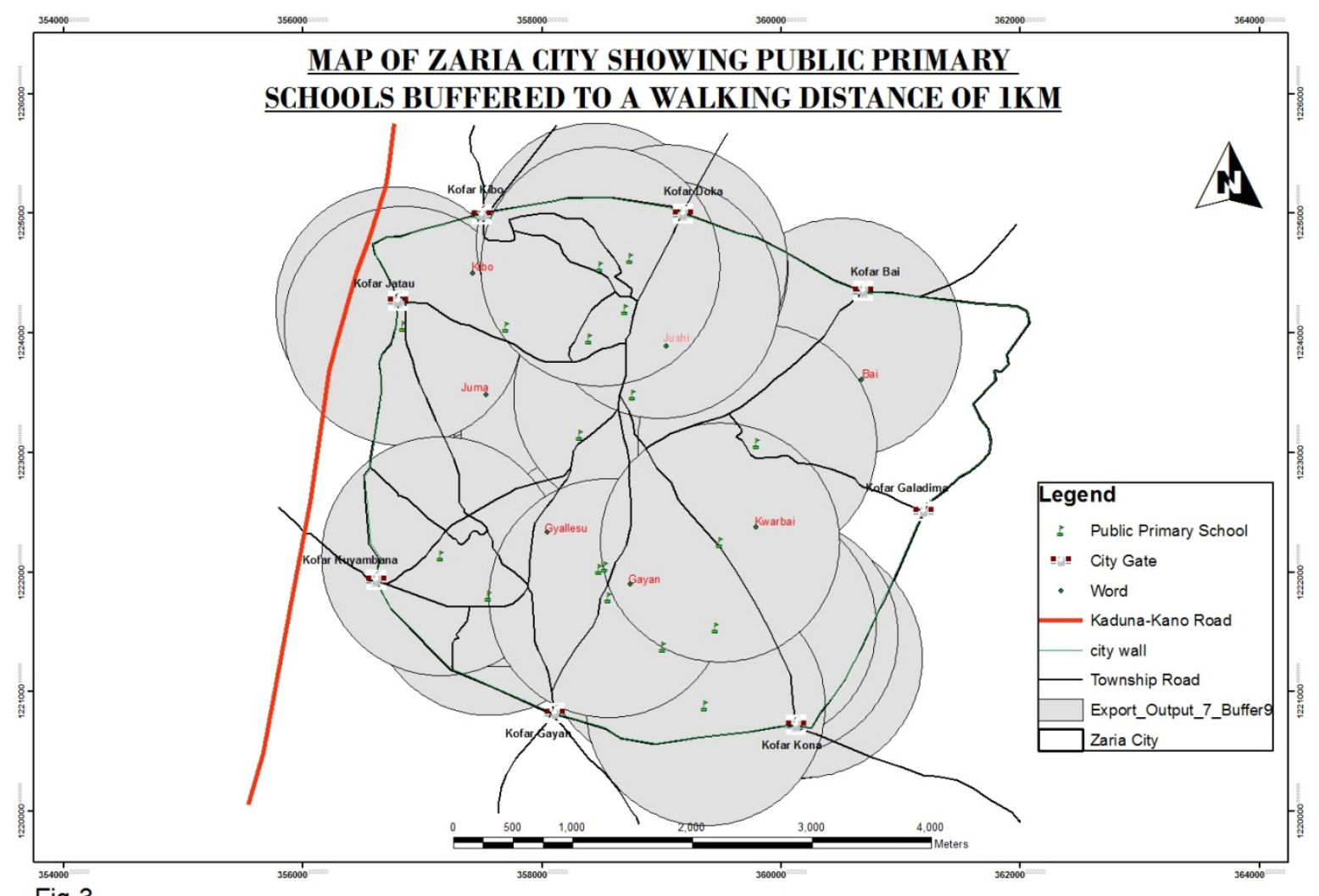

Fig. 3

Figure 5: Map of Zaria city showing public primary schools buffered to a walking distance of $1 \mathrm{~km}$

\section{Discussion}

As depicted in Figure 1, public primary schools almost evenly spread in the study area. It appears there was a deliberate attempt at achieving spatial balance in the distribution of the schools. While this appears to have been achieved to a certain extent, it is obvious that GIS technology was not used largely because of its relative recency. Access to the schools by pupils is correspondingly expected to be even. Table 2 shows that western style education started in 1921 in the study area. When viewed from the colonial history of northern Nigeria, this can be considered as early. The table also indicates that 11 primary schools were established in 1976, the year primary education was made free and compulsory in Nigeria. This was the highest number established in a year. Since 2007, no primary school has been added in the study area. Figures 2, 3, and 4 are demonstrations of how the data collected about the schools are queried using various themes and the resulting maps depicting the themes. Table 3 indicate that all the schools require additional classrooms. As a coping strategy, it is observed that the schools run two morning and afternoon shifts, i.e. some pupils attend school in the morning while others attend in the afternoon. The $1 \mathrm{~km}$ buffer zone for the schools indicates overlap of the zones. This suggests that, except for a personal preference for a particular school that may be far from their homes, no pupil treks for more than a kilometer to reach a school.

\section{Conclusion}

Thirty one public primary schools are in the study area. GIS methods were used to graphically depict the location of the schools the years they were established, their enrolment and, number of teachers and classrooms. The national teacher student ratio of 1:35 was used to determine the adequacy of classrooms and teachers available. All the schools require more teachers and classrooms to meet the required national standards. A buffer zone of $1 \mathrm{Km}$ was created for each of the schools to determine if the pupils have to walk longer than that distance to reach their schools. The schools were found to be evenly spread to allow access by pupils who do not have to walk more than a kilometer to reach their schools. 
The use of GIS in displaying educational information was demonstrated. As a consequence it is recommended that education authorities employ GIS methods to depict and analyse educational information because of the advantages they offer. Towards this end, efforts should be made to acquire the needed hardware, software and personnel.

\section{References:}

1. Aliyu, Y.A., Sule J.O., \& Youngu, T.T. (2012) Application of Geospatial Information system to Assess the Effectiveness of the MDG Target in Amac Metropolis- Abuja, Nigeria. J ournal of Environmental and Earth Sciences 4(3): 248-254.

2. Banskota, T.R. (n.d.) Application of GIS as Educational Decision Support System (EDSS): An Experience of Higher Secondary Education Board, Nepal. Retrieved from www.esri.com/library/ userconf/ educ09/ educ/ papers on 10th July, 2015.

3. Domike, G.C. \& Odey, E.O (2014) An Evaluation of the Major Implementation Problems of Primary School Curriculum in Cross River State, Nigeria. American Journal of Educational Research 2(6): 397-401.

4. FRN (Federal Republic of Nigeria) (2004) National Policy on Education. Fourth Edition. NERDC Press, Lagos, Nigeria.

5. Hite, S.J . (2008) School Mapping and GIS in Educational Micro Planning. Working Document, International Institute for Educational Planning (UNESCO)

6. Olubadewo, O.O., Abdulkarim, I.A., \& Ahmed, M. (2013) The use of GIS as Education Decision Support System for Primary Schools in Fagge Local Government Area of Kano State, Nigeria. Academic Research International 4 (6) ISSN2223-9553.

7. Sule, Abdullah and Bungwon (2012). The Acquisition of Geospatial Database for Primary Schools. A case study of Kaduna Metropolis, Kaduna State Nigeria J ournal of Environmental and Earth Science. 